\title{
“BETTER AND HAPPIER MEN AND WOMEN": THE AGRICULTURAL INSTRUCTION ACT, 1913-1924
}

\author{
Linda M. Ambrose
}

In 1913, the Canadian government introduced The Agricultural Instruction Act, a measure which granted ten million dollars to the provinces over ten years to aid agriculture. The Conservatives predicted that the Act would help in "aiding and advancing the farming industry by instruction in agriculture" but this paper argues that, ironically, the funding actually served to heighten rural discontent, not assuage it. By examining public documents and the rural press, the paper explores the rationale, rhetoric, and politics of this initiative. The funding designated for women's groups is closely examined to determine its impact on the growth of groups like the Women's Institutes.

En 1913, le gouvernement canadien adopta la Loi de l'Instruction agricole, une mesure qui octroyait 10 millions de dollars aux provinces sur une période de dix ans afin d'aider l'agriculture. D'après les Conservateurs, cette loi permettrait de soutenir et de faire progresser l'industrie agricole en misant sur l'enseignement dans ce domaine. On soutient ici, cependant, que, ironiquement, la subvention intensifia de fait le mécontentement du monde rural plutôt que de l'apaiser. S'appuyant sur des documents publics et la presse rurale, l'auteure de l'article explore le raisonnement, la rhétorique et les politiques de cette initiative. Les fonds attribués aux groupes de femmes sont minutieusement examinés afin d'établir leur effet sur la croissance de groupes tels que les Instituts féminins.

In January 1913, the Borden Conservatives introduced a bill in the Canadian House of Commons in which they proposed to grant ten million dollars to the provinces over a ten-year period as a form of aid to agriculture. While federal aid measures for farmers have since become an all-too-familiar necessity to help rural Canadians cope with crop failures or other natural disasters, this 1913 measure was different. It did not come in response to economic depression,

1 The author wishes to acknowledge funding from the Social Sciences and Humanities Research Council of Canada and the Laurentian University Research Fund. Julie Dion, Kristin Ireland, and Lee-Ann Spooner Fielding provided very capable research assistance and sound advice. An earlier version of this paper was presented at the meeting of the Canadian History of Education Association in Quebec City in October 2002. The author wishes to thank HSE's readers for their helpful suggestions.

(CHistorical Studies in Education / Revue d'histoire de l'éducation 16, 2 (2004): 257-85 
or to a crop failure, flood, or other natural disaster. Indeed, just eighteen months into the new Conservative Government's mandate, agricultural production had never been higher and farming was regarded as one of the mainstays of the burgeoning Canadian economy. This money was not targeted toward farmers' hardships, then, but on the contrary, it was said to be a means for the federal authorities to share the wealth with their agrarian partners. It was not directed at individual producers, and yet the Government hoped that this money would achieve certain educational ends for a particular group of people. ${ }^{2}$

When the Honourable Martin Burrell, the federal Minister of Agriculture, introduced The Agricultural Instruction Act to the Commons for first reading on January 24, 1913, he explained it was aimed at "aiding and advancing the farming industry by instruction in agriculture..." ${ }^{3}$ Public opinion was somewhat divided because, as one journalist writing for the Farmer's Advocate remarked, the Act was not defined precisely. "It is interesting to note that instead of the word Education, the framers of this bill have used the word Instruction to suggest their purposes. Now I find that this word has a very wide meaning...If they had in mind the full significance of the term they used, they have 'a charter as wide as the wind.'”4

The introduction of the Act coincided with a high level of rural political and social activism in Canada. For example, the United Farmers of Ontario, founded in 1914, would come to power in Ontario in 1919. ${ }^{5}$ At the same time, rural women's organizations were particularly strong, as evidenced by the Ontario Women's Institutes, which were experiencing unprecedented growth in membership and could boast of having almost 25,000 members by 1914. ${ }^{6}$ Indeed, with activism running high among rural people, the

2 Early in its first session, the Borden Government introduced two important pieces of legislation relating to farmers: The Canada Grain Act of 1912, and The Agricultural Instruction Act of 1913. For more on these two measures, see Vernon C. Fowke, Canadian Agricultural Policy: The Historical Pattern (Toronto: University of Toronto Press, 1946), 246-47. The other main issue that dominated this Parliament was the Naval Bill, a proposal to allot $\$ 35,000,000$ towards defence spending.

3 Honourable Martin Burrell, Debates of the House of Commons, 24 Jan. 1913, 214647; Canada, Debates of the House of Commons, 29 Apr. 1913, 8820; Debates of the Senate, 16 May 1913, 561.

4 Peter McArthur, "Matters Before Parliament," Farmer's Advocate, 20 Feb.1913, 317.

5 Kerry Badgley, Ringing in the Love of the Common Good: The United Farmers of Ontario, 1914-1926 (Montreal and Kingston: McGill-Queen's University Press, 2000).

6 Linda M. Ambrose, For Home and Country: The Centennial History of the Women 's Institutes in Ontario, 1897-1997 (Erin, Ontario: Boston Mills Press, 1996), 43. For more on rural women's activism, see Monda Halpern, And On That Farm He Had a 
introduction of a bill granting a large sum of public money to agricultural education garnered much public attention and stirred heated debates about potential outcomes.

What did the government of Canada hope to accomplish with this debatable proposal that was intended to provide such generous funds to farmers? Evidently the Conservatives were suggesting that rural education needed improvement. However, education in Canada is clearly a provincial matter; so exactly what kind of education was being proposed in this bill and why did it come before Parliament when it did? By examining public documents and the rural press, namely the Farmer's Advocate and the Weekly Sun, ${ }^{7}$ we can explore the rationale, rhetoric, and politics of this public funding initiative for rural education projects. This article examines the rhetoric that accompanied the introduction of The Agricultural Instruction Act and argues that the Borden government's funding for agricultural education actually served to heighten rural discontent rather than to assuage it.

It is important to note that in such public documents, the voices of women seem muted because most of those who spoke out about the Act were men: they were either members of parliament or journalists who critiqued their parliamentary deliberations. ${ }^{8}$ Yet this paper pays particular attention to women in two ways. First, it explores the assumptions about rural women that were implicit in the Act, such as the rhetoric about how women were viewed as agents of moral suasion. Secondly, this article seeks to analyze the level of financial assistance the Act provided directly to women in

Wife: Ontario Farm Women and Feminism, 1900-1970 (Montreal and Kingston: McGillQueen's University Press, 2001).

7 David C. Jones explored the rural press in order "to identify and assess the ideology of country living as it appeared in representative farm journals in the period 1900-1920," in "“There is Some Power About the Land": The Western Agrarian Press and Country Life Ideology," Revue d'etudes canadiennes/Journal of Canadian Studies 17, 3 (automne 1982 fall): 96-108. He listed the four major western Canadian farm periodicals as: The Nor-West Farmer (circulation 67,401); The Farmer's Advocate and Home Journal (40,917); The Grain Growers' Guide (74,606); and The Farm and Ranch Review $(48,844)$. In April 1919, the Weekly Sun, published in Toronto, was purchased by the Farmers' Publishing Company, renamed the Farmers' Sun, and declared to be "the official organ of the United Farmers of Ontario"; Halpern, And On That Farm He Had a Wife, 92.

8 In November 1917, the outspoken and highly political Emma Griesbach began to write for the women's page of the Weekly Sun, using the pen name "Sister Diana." Before that, the women's page, called "The Home Department," was decidedly apolitical, consisting of recipes, cooking hints, and household suggestions. See Halpern, And On That Farm He Had a Wife, 91-93. During the period when The Agricultural Instruction Act was being debated in the House of Commons and on the pages of the rural press, there was absolutely no mention of it in the women's pages of the Weekly Sun. 
an effort to keep them happy on the farm. The Agricultural Instruction Act made provision for a variety of rural education initiatives including assistance for agricultural colleges, direct instruction for farm producers, and activities for rural youth and for school children. In addition, some of the money was also targeted toward rural women's clubs like the Women's Institutes (WIs) and Homemakers' Clubs. ${ }^{9}$

HISTORIOGRAPHIC DEBATE about twentieth-century rural women's organizations has centred on the question of whether these groups were government strategies for exercising social control over rural women, or whether they were actually woman-centred sites for the celebration of women's culture and even feminist activity. Margaret Kechnie has argued that the Ontario provincial government, anxious to curb the trend of rural depopulation that was occurring in the years leading up to World War One, colluded with agricultural educators and rural and small-town elites to channel farm women into conservative programs like the Women's Institutes. She argues further that there were substantial problems with the way the groups were organized, and points out that one 1918 critic believed that "the WI should be 'scrapped to the junk heap' because of the control...the government exerted over it."10 The other side of this debate points out that while provincial governments did attempt to exert social control over rural women,

9 Ambrose, For Home and Country, and Women's Institutes in Canada: The First One Hundred Years, 1897-1997 (Ottawa: The Federated Women's Institutes of Canada, 2000); Catherine C. Cole and Ann Milovic, "Education, Community Service, and Social Life: The Alberta Women's Institutes and Rural Families, 1909-1945," in Standing on New Ground: Women in Alberta, ed. Catherine A. Cavanaugh and Randi R. Warne (Edmonton: University of Alberta Press, 1993), 19-33; Terry Crowley, "The Origins of Continuing Education for Women: The Ontario Women's Institutes," Canadian Woman Studies 7, 3 (Fall 1986): 78-81; Carol J. Dennison, "They Also Served: The British Columbia Women's Institutes in Two World Wars," in Not Just Pin Money: Selected Essays on the History of Women's Work in British Columbia, ed. Barbara K. Latham and Roberta J. Pazdro (Victoria: Camosun College, 1984), 211-19, and "Housekeepers of the Community: The British Columbia Women's Institutes, 1909-1946," in Knowledge for the People: The Struggle for Adult Learning in English-Speaking Canada, 1828-1973, ed. Michael R. Welton (Toronto: OISE Press, 1987), 52-72; E. Fletcher, History of the Manitoba Women 's Institute, 1919-1975 (Winnipeg: Manitoba Women's Institute, 1976); Marianne G. Otty, Fifty Years of Women's Institutes in New Brunswick, Canada 19111961: A History (New Brunswick: Women's Institutes, 1961).

10 Margaret Kechnie, Organizing Rural Women: The Federated Women 's Institutes of Ontario, 1897-1919 (Montreal \& Kingston: McGill-Queen's University Press, 2003), 132. 
the women defied government directives and refused to remain apolitical. Instead, women found these clubs provided a useful venue not only to lobby the government but also to organize on a local level for a variety of reform efforts. ${ }^{11}$ While this dichotomy is useful for the purpose of argument, the reality is that the two viewpoints are not mutually exclusive. ${ }^{12}$ Governments hoped to channel women in a certain way through providing such organizations, but the women themselves were selective about which aspects of the organization they actually welcomed.

The rising popularity of the Women's Institutes and related women's clubs just prior to World War One is striking. In virtually every province, some form of rural women's organization was in place by 1914. While official histories of the provincial associations explain this popularity as a happy coincidence and a sure sign that good ideas have a way of catching on, one cannot deny that the seemingly "spontaneous" popularity actually coincides directly with the creation of The Agricultural Instruction Act. When I became aware of this Act, then, I began to question previous conclusions about women and agency because it seemed that without the funding boost provided by The Agricultural Instruction Act, rural women's organizations might never have emerged when they did and with the strength that they did. I undertook this study of the Act in part to test those earlier conclusions about the Women's Institutes being a popular grassroots movement against this newfound information about federal funding as an explanation for the Women's Institutes' growth.

Moreover, there are striking parallels between Canadian Women's Institutes and the United States' rural women's club experiences that were emerging around the same time because of the American legislation known as The Smith-Lever Act (1914). ${ }^{13}$

11 Linda M. Ambrose, "What Are the Good of Those Meetings Anyway? Early Popularity of the Ontario Women's Institutes," Ontario History LXXXVII, 1 (Spring 1995): 1-19.

12 Linda Ambrose and Margaret Kechnie, "Social Control or Social Feminism: Two Views of the Ontario Women's Institutes," Agricultural History 73, 2 (Spring 1999): 222 37.

13 For more on The Smith-Lever Act see Philip A. Grant Jr., "Senator Hoke Smith, Southern Congressman, and Agricultural Education, 1914-1917," Agricultural History 60, 2 (Spring 1986): 111-22; Louis Ferleger, "Arming American Agriculture for the Twentieth Century: How the USDA's Top Managers Promoted Agricultural Development," Agricultural History 74, 2 (2000): 214-15; Dwayne Cox, "Alabama Farm Agents, 1914-1922," Alabama Review (October 1994): 285-86; and Jeffrey W. Moss and 
That American Act created educational services in each state for work among the rural populations. In particular, the funding was used to create the United States Department of Agriculture Cooperative Extension Service, which "transmitted the research expertise of federal agricultural experiment stations, the Bureau of Home Economics, and university agriculture and home economics departments into rural communities through a legion of county agents." ${ }^{14}$ Assuming that the Canadian and American cases might very well be a close parallel, I expected that my research might prove how funding from The Agricultural Instruction Act was largely responsible for the emergence of groups that emphasized education for rural women in Canada.

Historians have written very little about the Act with the exception of David C. Jones, whose 1978 doctoral thesis, "Agriculture, The Land and Education in British Columbia, 19141929," examined how it was applied to schoolchildren's education in British Columbia. Jones focused on the work of James Wesley Gibson, who served as Director of Elementary Agricultural Instruction for British Columbia from 1914 to1929. Through the lens of Gibson's bureaucratic career, Jones analyzed the schemes for rural elementary education that arose during the period of The Agricultural Instruction Act, concluding that after fifteen years, it "most decidedly had not solved the rural problem."

In Canadian social history, studies of the early part of the twentieth century have often ignored that "rural problem," concentrating instead on its corollary: the rapid urbanization and industrialization that was transforming central Canadian society. Far less attention is given to rural affairs during that same period and less still to rural people's own point of view. ${ }^{16}$ But apart from immigration, the second explanation for rapid urban growth was, of course, rural depopulation. That trend was particularly

Cynthia B. Lass, “A History of Farmers' Institutes," Agricultural History 62, 2 (1988): 161-63.

14 Mary S. Hoffschwelle, “'Better Homes on Better Farms'”: Domestic Reform in Rural Tennessee," Frontiers 22,1 (1996): 52.

15 David C. Jones, "Agriculture, the Land and Education: British Columbia, 19141929" (Ph.D. diss., University of British Columbia, 1978), 423. For another brief mention of The Agricultural Instruction Act, see Darius R. Young, An Historical Survey of Vocational Education in Canada, 2nd ed. (North York: Captus Press Inc., 1992); 12-16. 16 Charles M. Johnston touches on this issue in citing a 1911 issue of Farm \& Dairy that argued that a major explanation for rural depopulation was the poor treatment of farm hands by farm owners. "“A Motley Crowd': Diversity in the Ontario Countryside in the Early Twentieth Century," Canadian Papers in Rural History 7 (1990): 246. 
pronounced in rural Ontario, where the population was draining to rapidly growing cities and to the West. Population statistics show that by 1911, Ontario's rural population dipped below 50 per cent of the total population for the first time, a trend that would continue rapidly downward throughout the century. ${ }^{17}$ Meanwhile in "the Canadian prairie west...population jumped from 419,512 in 1901 to 1,956,082 in 1921."18 But even in the West, urban population growth was significant as compared to rural.

Schemes to curb the trend of farmers and their children flocking to the cities were very much under discussion at the turn of the twentieth century. Some people "were not so sure that the drain to the cities was not gathering up some of that best blood as well, and transfusing it into the urban economy which supposedly offered more to the enterprising farmer than did country life."19 Indeed, when Burrell introduced his bill to the House of Commons, he confessed that it was driven by two social problems: "the everincreasing cost of living, with its heavy burdens, and the increase of urban as against rural population." With this new legislation to promote agricultural instruction, the Minister hoped to curb both of these persistent problems. As he explained,

The two things are intimately related. Congestion in cities is both an economic and a social menace. The swelling of urban population with a diminution in the ranks of the producers has its sequence [sic] in the added cost of living, in the increase of squalor, hunger and crime, and - in a country to which thousands of immigrants come - in the concentration of large masses of the foreign born, who, when unassimilated and unrelated to our national life, constitute both a political and social difficulty." ${ }^{20}$

The Minister of Agriculture falsely concluded that better rural education would have the twin effects of keeping farmers on the land and increasing their productivity, which would at the same time lower the cost of living for urban consumers.

Canada was not alone in the rural depopulation trend, nor was it the first country to propose a scheme of funding for agricultural

17 See Randall White, Ontario 1610-1985: A Political and Economic History (Toronto: Dundurn Press, 1993), Appendix D, 340.

18 Jones, "There is Some Power About the Land," 96.

19 Good to S.F. Tilden, 12 Mar. 1916, cited in Johnston, “A Motley Crowd," 250.

20 Burrell, Debates of the House of Commons, 24 Jan. 1913, 2148. 
instruction as a solution to the phenomenon and its related problems. Burrell admitted that there were precedents to be found in several countries but in particular he cited Germany, Great Britain, Denmark, Belgium, and France. Of Belgium, he reported "depletion of soil and emigration of rural population became so serious that the Government in 1885 decided to appoint agricultural supervisors or district agricultural instructors. What has been the result? Briefly it may be summed up thus - increased values of farm lands, remarkable improvement in crop production and a steadying of the rural population." ${ }^{21}$ The secret to all that success rested in the fact that agricultural instruction had resulted in Belgian farms producing ten million pounds more each year than they had twenty-five years before. In France the results were equally impressive, and the Minister of Agriculture challenged his sceptics by quoting the Canadian Weekly Sun: "If anyone doubts the value of agricultural education when carried directly to the home, the barn and the field of the farmer, he should consider the case of France. Since that country established a practical system of agricultural education fifteen years ago the value of the annual crops has increased by five hundred million dollars."22

But some surely did doubt the scheme that Parliament was proposing. The most vocal opponents were the rural press, including the Weekly Sun, the very newspaper that Burrell had quoted. Indeed, the Sun's objections were repeatedly made clear: education was a provincial matter, not a federal one, and the real solution to farmers' economic troubles would be to reinstate reciprocity with the United States. Indeed, the front page of the 22 January 1913 edition of the paper did not mince words: "It is not so much more agencies of education that we need as a real Minister of Agriculture, who will vitalize the agencies already in existence."23 Cynicism about Burrell's proposal was echoed in a letter to the editor in the Farmer's Advocate that suggested that farmers needed more than ten million dollars in aid. What was really necessary, according to one writer, was exemption from taxes, raw materials duty-free, and cash handouts to pay employees. A tall order perhaps, but no more than the industrialists of central Canada were

Ibid., 2151.

Cited by Burrell, ibid.

"Dominion Aid to Agriculture," Weekly Sun, 22 Jan.1913, 1. 
enjoying. "Sure these aids have made the others millionaires - now let the farmers have them," the editorialist quipped. ${ }^{24}$

Like the cynical editorialist, Liberal members of parliament were not convinced that Burrell's proposed bill was really in the farmers' best interest. Indeed, the Opposition questioned the logic that suggested that increased production would either solve Canada's urban social problems or do much for the farmer himself. Michael Clark, the MP for Red Deer, Alberta, tried to follow the government's argument to its logical conclusion. "If you educate the farmer to a better production, you naturally make every farmer produce more," he began. Referring to the statistics that Burrell had cited from successful farm education programs in other countries, Clark continued, "If you could educate your farmers, spending ten millions [sic] in the process, to produce thirty-two bushels where they now produce seventeen, what will be the result? I believe there are one hundred million bushels of unmarketed grain in western Canada at the present time, of last year's crop, and if you double your production that means that in the spring you will have two hundred million bushels of unmarketed grain." ${ }^{25}$ Clark continued his argument from the farmers' point of view, suggesting that the best solution was not to increase production but to decrease it so that the market price would rise.

An editorialist in the Farmer's Advocate concurred with Clark's view. Increasing agricultural production would serve only "to reduce prices for most classes of farm products and to curtail profits. Is it much of a kindness to the farmer to accomplish that?" Indeed, the rural press was convinced that the Act was not really drafted with farmers in mind at all. "But do we not wish to see the farmer more highly educated, and have him produce larger crops? Most assuredly we do, so long as it is going to benefit him individually....But the motive behind all the propaganda work [of the Act]...is a selfish one, and conceived not in the farmer's interest, but in the interest of city people." ${ }^{26}$

Of course, by suggesting that the government should take responsibility for finding markets for the excess grain already produced by western farmers, Liberal MPs were playing partisan politics. Their arguments made direct reference to the issues of reciprocity and the fact that western farmers were not happy with

Farmer's Advocate, 3 Apr. 1913, 630.

Clark, Debates of the House of Commons, 18 Apr. 1913, 8068.

Farmer's Advocate, 25 Sept. 1913, 1669. 
the outcome of the 1911 general election and the defeat of the Laurier Liberals' platform of free trade with the United States. During that election campaign, Conservative leader Robert Borden had promised that he would "provide for the liberal assistance to the provinces for the purpose of supplementing and extending the work of agricultural education and for the improvement of agriculture.” As Borden's Minister of Agriculture, Burrell explained that the bill "was intended to be a prompt and complete fulfillment of that promise." 27 This was the Conservatives' attempt to heal the election rift between Central Canada's interests and those of the West.

Yet the agricultural press made very clear their view that the proposed Act would not suffice. In an article entitled "Hon. Mr. Burrell's Agricultural Policy," the Weekly Sun did not dismiss the idea of federal involvement in agriculture. On the contrary, the writer argued, "There is room for real service by the Federal Administration. The opening of the American market to the natural products of the soil, which may even yet be secured by acceptance of the American offer of Reciprocity, would do more for the prosperity of the agricultural interest than the best educational scheme the wit of man could devise." 28 According to economic historian Vernon C. Fowke, The Agricultural Instruction Act "was but slight compensation to western farmers for the rejection of their demands for reciprocity with the United States." 29 Slight compensation indeed, considering how little the western provinces received compared to Ontario and Quebec. The funding formula for the Act was based on total provincial population, not percentage of rural population, and as a result it did not help the West as much as it helped the more populous provinces of central Canada, specifically Ontario and Quebec. For example, in 1915-16, while Ontario received \$266,014 and Quebec \$215,311, Alberta and Saskatchewan received \$56,529 and \$68,011 respectively. ${ }^{30}$

Beyond the politics of all this, the rhetoric about farmers that surfaced during the debates on the bill is fascinating. Not surprisingly, each party claimed to know what was best for the farmers of the country. Meanwhile, farmers were suspicious about how well they were actually being represented in parliament.

Debates of the House of Commons, 24 Jan. 1913, 2147.

"Hon. Mr. Burrell's Agricultural Policy," Weekly Sun, 5 Feb. 1913, 1.

Fowke, Canadian Agricultural Policy, 246-47.

The Agricultural Gazette 2,7 (July 1915): 621-22. 
"Farmers, hard-working men, compose seven-tenths of the population, and produce seven-tenths of the wealth of the country but when it comes to being represented in parliament where they could have a say in how the wealth they produce should be spent, they tell me you can count the real farmers on the fingers of one hand or five out of a total of two hundred and twenty." ${ }^{31}$ Concern over the profile of members of parliament would only serve to fuel the fire of rural political movements like the United Farmers as agriculturalists sought direct representation of their views in parliament.

The shortage of farmers equipped to serve as MPs could be explained in part by the fact that the agricultural colleges were failing to attract students from the farm the way promoters had hoped they would. The MP from the North Oxford riding in Ontario pointed out that "the young fellows who go there [to agricultural colleges] do not come back to the farm for some reason; perhaps they take up the teaching profession. A great many of them are town fellows [not farmers]." ${ }^{32}$ What seemed to be happening was that these formal education facilities were actually attracting more town than country folk, and to make matters worse, the graduates of these institutions did not usually return to the farm. ${ }^{33}$ More were destined for the professions, whether that meant teaching in the colleges or schools, or working as agriculture bureaucrats in government positions. Those in this category could be called the "elite" of the agricultural community, though practicing farmers were more likely to refer to them as "book farmers."

At the opposite end of the spectrum were farmers who refused to learn how to improve their practices. This group was described variously in terms of their struggles, both economic and psychological. Rural reformers, who loved to escape to the country to appreciate the beauty of nature, were frustrated by the fact that farmers failed to appreciate the beauty around them. Country-life ideology was clearly at work in the midst of the rural depopulation crisis. ${ }^{34}$ As David Jones has argued, "It is the nature of societies to

\footnotetext{
31 Farmer's Advocate, 19 June 1913, 1108.

Debates of the House of Commons, 24 Jan. 1913, 2156.

John MacDougall, Rural Life in Canada: Its Trends and Tasks (Toronto: The Westminster Company Ltd., 1913), chap. 4, "Social Causes of Unrest," and 138.

34 For more on the country-life movement in the United States, see David B. Danbom, Born in the Country: A History of Rural America (Baltimore and London: The Johns Hopkins University Press, 1995), 167-75.
} 
attempt to identify and define themselves...If contrary ideals are perceived as threats, it is not unusual for spokespersons of the emerging culture to construct an elaborate ideology which justifies the preferred ideals. Such ideology of course is simultaneously defensive and highly positive." 35 MacDougall's 1913 book on rural life in Canada was typical of that positivist thought. He remarked that "with some who dwell in the country, all nature is so intimately blent with associations of toil that it cannot be looked upon with pleasure."36 The problem was economic, but coupled with it was the mental toll. MacDougall and like-minded reformers were convinced that this could change, not by changing the economic circumstances necessarily, but by awakening a "latent sensibility" of "nature-love." This idealism carried over to policy-makers who believed that education for rural living would lead to greater fulfilment among Canadian farmers. As the Conservative members argued during debates about The Agricultural Instruction Act, "We want to make better farmers and better and happier men and women." This powerful positivist country-life ideology must be recognized as a driving force behind policy-making. ${ }^{37}$

Ensuring the happiness of rural women was a particularly important piece of the solution to the rural depopulation puzzle, according to commentators on rural life. MacDougall, in Rural Life in Canada, described his encounter with a woman who resented her difficult economic circumstances. "One day a few of us were off for a tramp over the hills," he recounted. "Coming across some berry pickers we bought a few berries. As we paid a woman for them I said, 'What a glorious view you have from these hills!' With mild profanity but with strong feeling she replied: 'You wouldn't think so darn much of it if you had to make a living here picking blueberries." "38 MacDougall interpreted that woman's pent-up resentment as symptomatic of the plight of poor farmers. Reflecting on that conversation in the blueberry patch, one can see that producers and the so-called "experts" who prescribed idealistic remedies for curing rural frustration perceived rural problems very differently.

In the same context, MacDougall continued his lament of the fact that farmers did not appreciate their idyllic settings by citing

Jones, "There is Some Power About the Land," 96.

MacDougall, Rural Life in Canada, 142.

Jones, "There is Some Power About the Land," 106.

MacDougall, Rural Life in Canada, 142. 
the English writer Henry Ryecroft, who claimed that "in days gone by the peasantry found life more than endurable...The fact that flowers and birds are well-nigh forgotten, together with the songs of the elves, shows how advanced is this process of rural disintegration." 39 As the blueberry picker probably would have wanted to point out to these gentlemen strolling through the hills, solving rural discontent would take much more than their idealistic proposals. The idealism they spouted was part of what David Jones has called the "rural myth." According to Jones, "this myth was essentially positive and optimistic; those who believed felt generally that the land being occupied was livable, that man with the aid of science could subdue nature and pave the way for an era of agrarian splendour." ${ }^{40}$ In some cases, farmers themselves subscribed to the myth because it "reassured them of their place in society and, once they felt they knew their role, they were able to formulate a critique of their society." 41

While there were the romanticists, other rural experts such as Professor J.B. Reynolds of the Ontario Agricultural College took a very different approach. When Reynolds spoke to a series of farmers' meetings in March 1913, he asked, "What makes farm life attractive?" His conclusions stood in stark contrast to the rural myth that MacDougall promoted: "All the talk of the beauties of nature and the charm of farm life he called 'poppycock.' People cannot live on it, and until our living is certain there is no use of talking 'fresh air,' 'nature,' and 'independence.'"42 Reynolds suggested that the answer to stirring up greater interest in farming lay in making it "an intelligent occupation" based on scientific and business principles, not poetry.

If men needed more science and business to make farm life attractive, the Farmer's Advocate argued that women also needed more than poetry. Reprinting a lecture delivered in Washington, D.C. by W.J. Kennedy, the Director of Agricultural Extension at Iowa State College, the newspaper identified five "fundamental

39 Ibid., 141-42. For other examples of this idealist rhetoric, see Jones, "There is Some Power About the Land," 98, 99.

40 Jones, "There is Some Power About the Land," 96.

41 Kerry Badgley, "The Social and Political Thought of the Farmers' Institutes of Ontario, 1884-1917" (M.A. thesis, Carleton University, 1988), 52-53. For more on the rural myth and its attraction for rural people, see Russell Hann, Farmers Confront Industrialism: Some Historical Perspectives on Ontario Agrarian Movements (Toronto: New Hogtown Press, 1975).

42 Farmer's Advocate, 20 Mar. 1913, 519. 
reasons as to why the country woman, the country boy and the country girl become dissatisfied with farm life." The reasons included: the drudgery of the work; the lack of social outlets; the inadequacy and misdirection of educational facilities; the decadent condition of country churches; and the poor roads that were seasonally impassable. Kennedy had suggested a list of solutions to these problems, laying out a program for extension workers. "What farm families wanted," according to the Farmer's Advocate, was less rhetoric about education, and some basic community organization. That opportunity for rural community organization is precisely what groups like the Women's Institutes provided. ${ }^{43}$ Clubs for rural women, like the Women's Institutes, were stepping up to fill that void but in order to do so, they needed farm people who would take the initiative as leaders and organizers within their communities, rather than relying on the expertise of outsiders. Expertise from within would arise, according to Kennedy, if the education system began "to dignify the two greatest of our industries: agriculture and homemaking." 44

But at least one Canadian Senator maintained that while "class" divisions among farmers would continue to exist, the Old Country model did hold the solution to Canada's agricultural crisis. In fact, Senator George Ross proposed a system that would create and systematize these class divisions more formally. Specifically, he proposed that a system of farm labourers' cottages should be built so workers could take up residence on their bosses' land as tenant farmers. This should be encouraged, he argued, because it would solve the farm labour shortage, provide rural domestic help, and free the farm owner to develop his mind and intellect. ${ }^{45}$ No matter where one stood on the idea of emulating the English model, there was something in the Senator's argument upon which everyone could agree: namely, that farming in Canada was by no means a classless sector. While politicians disagreed about whether farmers needed to produce more or have better access to markets, both parties agreed that the category of "farmer" was not homogeneous. They indicated that there were different sectors or what they called "classes" of farmers. There were prosperous farmers who got that way because of their willingness to receive instruction, and there

Ambrose, "What Are the Good of Those Meetings Anyway?" 11-15.

Farmer's Advocate, 4 Dec. 1913, 2124-25.

Debates of the Senate, 8 May 1913, 476. 
were the so-called "ordinary" farmers who were of a somewhat lower class and were reticent to receive advice.

As Charles Johnston has argued, farm leaders made an assumption that for those who aspired to take up a career in farming, "there would be an orderly progression up a clearlyrunged rural ladder." Indeed, students at the agricultural colleges were told stories "of how intelligent high school graduates made such a speedy profit out of their rented farms that they were soon in the happy position of being able to buy their own." ${ }^{46}$ But as Johnston pointed out, the majority of rural youth did not possess a high school education, and without it, their chances of climbing the agricultural ladder were seriously diminished. Although academic analyses of class structure have concluded that farming seems to "defy any known code of stratification," playing field for all participants. In short, farmers were not a homogeneous social group.

As the debates about the proposed Agricultural Instruction Act continued, Opposition MPs cautioned the Government members that farmers in their constituencies would take offence at some of the descriptions being tossed around during the debates. Their argument was not that it was offensive to consider less prosperous farmers simple-minded. Rather, as one Liberal member argued, the well-to-do farmers in his riding would be offended at the suggestion that they needed government aid at all. ${ }^{48}$ In his mind, farmers were an independent, proud, hard-working lot who were only being held back by government decisions that hampered their prosperity.

Yet politicians from both parties who favoured the instruction act scheme agreed about the type of education that was necessary for farmers. Spurning the idealism of country-life advocates who thought that poetry and theory would inspire or challenge the farming community, they called instead for practical, applied, vocational education. In particular, they were convinced that demonstration methods were the most likely to succeed. James Wilson, the U.S. Secretary of State for Agriculture from 1897 to 1913, explained in 1910 that "demonstration work simply means showing people who are not as good farmers as they might be what

Johnston, "A Motley Crowd," 245.

Ibid., 238.

Debates of the House of Commons, 24 Apr. 1913, 8525. 
good farmers throughout the world have known for some time."49 In Canada, legislators and senators focused mainly on one particular method of demonstration: the experimental farm. The purpose of experimental farms was to showcase recent innovations in agricultural research, both in horticulture and livestock. ${ }^{50}$

In a cost-cutting argument, some suggested that one national farm (like the one in Ottawa) would suffice, and that results from tests conducted there could be communicated throughout the country through printed information or travelling lecturers. Of course that argument did not sit well with MPs whose ridings already contained an experimental farm, or with those who hoped soon to acquire one for their constituents. Even among those who accepted that the country needed more than a few of these farms, the same fiscally conservative thinking surfaced when they argued that experimental farms should not be duplicated across the country. Senator Ross from Middlesex County in Ontario questioned whether duplication was not a waste of precious resources. He was convinced that raising hogs in one place would be sufficient, while other farms should do other experiments. The resulting information could be shared, he thought, through publications and lectures. ${ }^{51}$

But those who claimed to know farmers best vehemently disagreed with the idea of centralized farms or dedicated projects or more publications and lectures. Their opposition was only partly politically driven by self-interest in their own ridings. The argument centred more on the type of education that was most appropriate for farm people. It had to be practical. It had to be visual. And it had to be local. According to the Honourable Mr. Robert Watson, a Senator from Portage la Prairie, Manitoba, "It would be a good thing for Canada to have a demonstration farm every twenty-five miles, where people could see for themselves what is being done." ${ }^{\text {"2 }}$ Watson was convinced that farm folks were not readers, but doers. Similarly, Charles Johnston discusses the

49 James Wilson, cited in Louis Ferleger, "Arming American Agriculture for the Twentieth Century," 217-18. In the United States between 1907 and 1911, the Extension Service made use of railway trains as a venue for travelling demonstrations. At its height, "in 1911, 71 educational trains carried 767 lecturers through 28 states." Moss and Lass, “A History of Farmers' Institutes," 158-59.

50 For more on experimental farms in the United States, see Lou Ferleger, "Uplifting American Agriculture: Experiment Station Scientists and the Office of Experiment Stations in the Early Years After the Hatch Act," Agricultural History 64, 2 (1990): 5-23. 51 Debates of the Senate, 15 May 1913, 535.

52 Ibid., 535. 
disdain that some farmers held for higher education, noting that "there would be many a farmer, affluent or otherwise, who would recoil from the teachings and refuse to follow the example of their supposed betters who had received the dubious benefits of higher education." $" 33$

To facilitate the kind of applied instruction that the Act's creators proposed, setting up experimental farms was only one of the most obvious methods. Even more promising, some argued, were actual visits to individual farms where consultation, advice, and instruction could take place one-on-one. That of course, would involve even more personnel. In 1913, John R. MacDougall reported that such instructors, or "agricultural representatives," were firmly established in Ontario: "Ontario alone employs over a hundred trained, skilled, competent agriculturalists, teaching, and traveling over the Province furnishing information and advice upon farm conditions and possibilities...[one expert comments that]: 'In those regards Canada is in the front rank among all the nations of which I have any knowledge." "54 This was a close parallel to the American model where the goal of the United States Department of Agriculture Extension Service, funded by The Smith-Lever Act, was to place one agricultural representative in every county of every state. As Louis Ferleger has noted, "Ten years after the passage of The Smith-Lever Act, there were 2,500 county agents in the United States spread out over about three-quarters of the agricultural counties in the nation. Not only did information flow back and forth between extension agents and farmers, the county agents played a central role in organizing farmers on the local level for purposes of education and sharing information." 55

But the creation of all these new positions for agricultural representatives only served to reinforce doubts among farmers about the federal funding program and its effectiveness. An editorial in the Weekly Sun, entitled "How Farmers May be Helped," questioned how the money was being spent. "We doubt not that the greater portion of this $\$ 10,000,000$ will be spent in salaries and general management of the fund, and that a very small fraction will benefit but a small fraction of the farmers of Canada."

53 Johnston, "A Motley Crowd," 252. He also cites a short story by Nellie McClung, published in Farm and Dairy, in which one of the characters announced that "Her Tom," freed from "the pack of nonsense learned at school...would be the richest man in the valley" (252).

54 MacDougall, Rural Life in Canada, 245.

55 Ferleger, "Arming American Agriculture for the Twentieth Century," 215. 
Instead of more agricultural representatives, the editorialist suggested something that he considered much more cost-effective: "reduce the duties on farm implements for ten years. This would benefit every farmer and cost nothing to administer the fund." 56

While reducing tariffs was not part of the plan, hiring additional agricultural educators was one of the centrepieces of the proposal. For the most part, in both the U.S. and Canada, these agricultural representatives were younger than the farmers they advised, and this highlighted the fact that even while the Canadian bill was being considered in the Legislature and Senate, discussion about farmers centred on the age of the farmer. The problem of rural depopulation, after all, was largely about the migration of young people away from the farms and into the cities. The result, it seemed, was that the potential for change in the countryside left when the youth departed. Critics viewed older producers as too "set in their ways" though not completely unteachable if the right approach was taken. That approach would inevitably involve reaching the farm youth. ${ }^{57}$

To train youth, post-secondary institutions seemed an obvious choice of venue, with agricultural and veterinary colleges a principal target; but the majority of the graduates from those institutions did not take up farming directly. ${ }^{58}$ What better target, then, than those who were younger still? School-aged children became a prime focus of programs established under The Agricultural Instruction Act because, as Danbom has argued about the United States, "the schools dealt with children, who were more pliable than adults. To truly endure, changes in rural society had to begin with children." 59 The Act became synonymous with three different kinds of instruction for children: gardening, both at school

\footnotetext{
56 "How Farmers May Be Helped," Weekly Sun, 19 Mar. 1913, 3.

57 The Ontario Junior Farmer Club movement was designed in part to involve farm youth in educating their parents. See Linda M. Ambrose, "Cartoons and Commissions: Advice to Junior Farmers in Postwar Ontario," Ontario History XCIII, 1 (Spring 2001): 57-79.

58 For more discussion about why agricultural college graduates did not return to the farm, see David C. Jones, “'We Can't Live on Air All the Time': Country Life and the Prairie Child," in Studies in Childhood History: A Canadian Perspective, ed. Patricia Rooke and R.L. Schnell (Calgary: Detselig, 1982), 190-93, where the author discusses a four-part series published in the Farmer's Advocate and Home Journal in 1918 on this question.

59 Danbom, Born in the Country, 169. For examples of projects that were funded among Canadian schoolchildren, see the various issues of the Agriculture Gazette.
} 
and at home; school agricultural fairs; and boys' and girls' clubs. ${ }^{60}$ David Jones has pointed out the implicit philosophy behind these child education schemes. In British Columbia, educators insisted that planting a garden was not as much about planting a garden as it was about shaping character. The line between vocational and cultural/moral education was blurred. Funding programs for children and youth were clearly attempts to curb the rural depopulation trend by helping children find stimulation in rural life, so that they would be less likely to leave for the city when the opportunity arose. ${ }^{61}$ It was also an attempt to prepare farmers' children for life-long learning that would make them more receptive to instruction from rural experts when they reached adulthood. ${ }^{62}$ But meanwhile, proponents of agricultural education for children also hoped that the biblical principle would hold true: "a little child shall lead them." In other words, instructors of children hoped that their parents would become curious enough, through their children's activities, to seek out better means to increase adult production on the farm.

In this exercise in cultural reproduction, women were to play a key role in nurturing children into a love of the land. In all of these initiatives with children, the involvement of rural women was assumed. Indeed, most of the provinces counted on the formal and informal support of women to make the schemes work, particularly school fairs, home gardening, and clubs for boys and girls sponsored through the Departments of Agriculture. Given the emphasis on women as nurturers, and even as nation-builders, this is not surprising. In her 1978 study of imperialism and motherhood, Anna Davin highlighted the important role of women's voluntary societies for the proliferation and inculcation of

60 For more on school gardens, see Young, An Historical Survey of Vocational Education in Canada, 15; Lyle Dick, "The Greening of the West: Horticulture on the Canadian Prairies, 1870-1930," Manitoba History 31 (1996): 16; and Jones, "There is Some Power About the Land," 99. A critical analysis is found in Jones, "We Can't Live on Air All the Time," where he explains why "the rural life propaganda which issued from so many sources fell on deaf ears, why in fact, prairie youth left the farm": 186.

61 The relative success of these schemes was meagre at best. While the country-life ideal presented through the curriculum and extra-curricular activities held out various rationales for staying on the farm, the option to leave the land was reinforced through children's own experiences and their parents' decisions and strategies. See Jones, "We Can't Live on Air All the Time," 188-97.

62 The same strategy was in place in the United States where clubs for youth "became the connecting link between the agricultural club movement in the rural schools and the regular farmers' institutes for adults." Moss and Lass, "A History of Farmers' Institutes," 161. 
specific moral values, and historians of Canadian women have amply demonstrated that the same phenomenon was at work in this country as well. ${ }^{63}$

Women who were active in rural organizations such as the Women's Institutes and Homemaker Clubs were critical of the fact that government support for farmers most often ignored the needs of women. One vocal critic was Mary Urie Watson, Principal of the Macdonald Institute in Guelph, a domestic science education facility for rural women. After ten frustrating years of low enrolment in her institution, Watson could have offered a variety of explanations about why rural girls and women were not flocking to her school, including the fact that most females from rural communities could not meet the admissions requirement of a secondary school diploma. But the chief reason she gave had to do with the existing distribution system of government funds. In 1913 the Macdonald Institute launched a series of domestic science education courses by extension, an important new initiative in conjunction with the Ontario Women's Institutes. ${ }^{64}$ Just one year earlier, Principal Watson had overtly criticized the Ontario Government for discriminating against women in the distribution of its rural education dollars. "Why should the women not claim some of Ontario's wealth from the government?" she demanded. Speaking before the Annual Convention of the Women's Institutes, she challenged her listeners to ensure that women received their fair share of government funds. She referred to the provincial government's investment in male agricultural representatives when she asked, "Do you know what the work in each county cost for salaries and traveling expenses and maintenance? \$2100. Do you know the average amount per county the Women's Institute work

63 Anna Davin, "Imperialism and Motherhood," History Workshop 5 (1978): 12. The same expectation that women were charged with transmitting certain moral values to children has been consistently found by Canadian historians as well. See for example Cynthia Comacchio, The Infinite Bonds of Family: Domesticity in Canada, 1850-1940 (Toronto: University of Toronto Press, 1999), 58; Nancy Christie, Engendering the State: Family, Work and Welfare in Canada (Toronto: University of Toronto Press, 2000), 1056; and Mariana Valverde, “'When the Mother of the Race is Free': Race, Reproduction, and Sexuality in First-Wave Feminism," in Gender Conflicts: New Essays in Women's History, ed. Franca Iacovetta and Mariana Valverde (Toronto: University of Toronto Press, 1992), 3-26.

64 See Ambrose, For Home and Country, 51; Terry Crowley, "The Origins of Continuing Education for Women: The Ontario Women's Institute," Canadian Woman Studies 7, 3 (Fall 1986): 78-81. 
costs? An average of $\$ 125.00$. The disparity is too great when the relative importance of the two branches of work is considered." 65

Watson was aware of the fact that agricultural experts were meeting with some resistance from male farmers who did not welcome government intervention in their farming practices, and she argued that women were much more open to instruction and therefore a better investment of public monies. "[The] Department [of Agriculture] might leave those indifferent farmers to ripen a bit and transfer their attention to harvesting a crop of extension classes amongst the women who are hungry for more instruction about their special work. We can assure them of enthusiastic support." 6 While there is no evidence that they were doing so in direct response to Watson's criticisms, several Canadian provinces did use some portion of their funds from The Agricultural Instruction Act to make direct provisions for instructing rural women themselves, not just their children. In March 1920, The Agricultural Gazette, a newsletter published to report on the Act's expenditures, included a special report on "Women's Institutes." The report made it clear that "the work of these organizations in all the provinces except British Columbia is assisted, to some extent, by funds under The Agricultural Instruction Act." ${ }^{67}$ Table 1 (on page 284) shows the provincial allotments of those funds that went to rural women's organizations in each province in 1920.

The bulk of the funding designated for women went into the coffers of rural women's organizations such as Women's Institutes or Homemakers' Clubs. Begun in 1897, domestic science clubs for women took hold throughout Ontario and across Canada, and the movement experienced tremendous growth over the next fifteen years. ${ }^{68}$ By 1913 when The Agricultural Instruction Act funds began to be distributed, Women's Institute members were already considering the need for some national organization to tie the provincial clubs together. Hopes for federal funding ran high when representatives from various Women's Institute groups met together in Winnipeg in February 1913. Feminist leader and prolific Canadian author Emily Murphy, also known as "Janey Canuck," hoped to persuade the authorities in Ottawa that it would

65 Mary Urie Watson, quoted in Ontario, Department of Agriculture, Annual Report of the Institutes Branch of the Ontario Department of Agriculture, 1912, 65-66.

66 Ibid., 66.

67 The Agricultural Gazette 7, 3 (Mar.1920): 232.

68 See Ambrose, "Branching Out: Years of Growth, 1904-1914," in For Home and Country, 39-62. 
be a legitimate use of the Act funds for the Government of Canada to pay to establish a national federation of Women's Institutes. Of course, under the terms of the Act, monies were transferred to the provinces, not directed to the creation of national bodies. The attempt to find funding through this Act in order to establish a national federation of rural women's clubs failed. ${ }^{69}$

However, some money from The Agricultural Instruction Act was designated for women, particularly through women's clubs. In some provinces, such as Quebec and Manitoba, the money was directed toward providing instruction in household science rather than directly to the Women's Institutes or Homemakers' Clubs. As a percentage of the total grants going to each province, women's work in 1920 only accounted for 3.44 per cent of the total expenditures. In some individual provinces, the money earmarked for women's work was sometimes as high as 14 per cent (New Brunswick and Alberta), but in others, it was consistently kept very low. For example, Ontario only directed 1.49 per cent of the total money toward Women's Institutes.

In straight dollar amounts, the sums allotted to the Women's Institutes ranged from nothing at all (British Columbia) to between $\$ 2,566$ (Prince Edward Island) and \$9,500 (Alberta) in the budget year 1920-21. Ontario received more than $\$ 335,000$ per year in the final years of the program and the amounts given over to women's organizations ranged from less than 1 per cent up to 3.32 per cent of the total grant monies. Provinces that were much smaller in terms of their total population (and therefore total grant received) managed to set aside a much more respectable sum for women's work. For example, Prince Edward Island, which only received about one-tenth the amount of money given to Ontario, consistently put aside an average of 11 per cent for the work of Women's Institutes.

No wonder Principal Watson and her contemporaries felt that the Government of Ontario was short-changing its rural women by holding back funds under the Act from women. Adelaide Hoodless, when she was advocating organizations for rural women in the 1890s, had accused men of being more concerned with the science of raising livestock than the science of raising their

69 For more on the plans to form a national federation of Women's Institutes, see National Archives of Canada, Federated Women's Institutes of Canada, MG 28 I 316, Vol. 7, File 15, Rutman-Watt correspondence, 1912-1913. 
children. ${ }^{70}$ Her rhetoric about investing in families rather than pigs and cattle was still popular among Women's Institutes leaders almost twenty years later, and it proved useful for women to plead for more funding for their clubs. Of course women's organizers would argue that the money was never enough. Yet, given the context of early-twentieth-century rural society, the fact that women's club work was funded at all is noteworthy.

It seems logical to assume that this funding would serve to explain why rural women's groups flourished in the period leading up to 1920. Grassroots explanations cite women's interest in these organizations and their agency in calling for the establishment of Women's Institutes and Homemakers' Clubs. Yet the fact remains that to organize these clubs took money, and for the ten years of The Agricultural Instruction Act, money was available to local women's clubs through the provincial allotments under the Act. Like the funds directed to elevating rural schoolchildren, the direction of funds toward women's club work was in part based on the country-life idealism that asserted that wives were a major factor in men's decisions to abandon farming for city life. The rationale was that if the women could be more content with rural living, then the trend toward rural depopulation might begin to be reversed. Therefore, a portion of The Agricultural Instruction Act funds was directed to women's work.

My hypothesis when I began this research was that such funds might help to explain the rapid expansion of rural women's groups across the country. But a closer analysis of the funding channelled toward women casts doubt on that idea. The case of Ontario illustrates this point. As the most populous province, Ontario received \$336,303.26 from The Agricultural Instruction Act in 1920. As the birthplace of Women's Institutes, Ontario also boasted the highest Women's Institutes membership in the country, with 30,000 women that year. One would expect, therefore, that Ontario Women's Institutes branches were the most highly funded in the country. However, as the provincial government chose to direct only 1.49 per cent of that money $(\$ 5,000)$ toward Women's Institutes activity, Ontario's WI members were among the lowest

70 See Ontario Women's Institute Story: In Commemoration of the $75^{\text {th }}$ Anniversary of the Founding of the Ontario Women's Institutes of Ontario (Federated Women's Institutes of Ontario, 1972), 6. 
funded in the country, as Table 2 (page 285) illustrates. ${ }^{71}$ There was no cause-and-effect relationship between The Agricultural Instruction Act funding and club participation rates in 1920. Women's Institutes clubs were popular among Ontario's rural women, and they were supported financially by the provincial Department of Agriculture, but they were not generously funded by the proceeds of the Act. Indeed, although that funding was welcome and significant, it alone does not account for the growth of the Women's Institutes.

Despite the popularity of Women's Institutes and their relatively low cost, politicians were still concerned about rural depopulation. And they remained convinced that female contentment with rural living was a key to reversing that problem. But how could women be made more content? How could they be made "better and happier" women? The commonly held assumption was that by alleviating her sense of isolation in the country, and by introducing her to the amenities of city living, the urge of the rural woman to abandon country living would be assuaged. The Farmers 'Advocate reported on a list of some of the suggested amenities to which farmwomen should have access. According to American extension worker W.J. Kennedy of Iowa State College, women wanted and needed labour-saving devices in the kitchen; the use of mechanical power for washing, ironing, churning, and sweeping; the installation of a modern water and sewage system; the installation of a modern heating and lighting system; the presentation of carefully worked-out plans for a comfortable and practicable farm home; sensible suggestions on the decorating and furnishing of the farm home; and helpful hints on the planning and adorning of the farm lawn. ${ }^{72}$

71 Figures for Quebec and Manitoba are not available because these two provinces failed to differentiate in their budget reports between Domestic Science funding (including schoolchildren) and Women's Institutes. Although one might imagine that the Ontario clubs were well endowed because of income from membership fees, this was not the case. Each woman was expected to pay only twenty-five cents per year, a rate that was constant from 1897 to 1949 (when it doubled to fifty cents a year), in an effort to make the clubs accessible to the largest possible number of women. On Women's Institutes membership fees, see Ambrose, For Home and Country, 26, 108, 129, 156.

72 Farmer's Advocate, 4 Dec. 1913, 2124-25. American author Virginia Scharf has argued that by their example, extension service workers funded by The Smith-Lever Act introduced rural women to the freedom afforded by the automobile; see Scharf, Taking the Wheel: Women and the Coming of the Motor Age (Albuquerque: University of New Mexico Press, 1991), 143. I would like to thank Kristin Ireland for bringing this reference to my attention. 
These were the very things that Women's Institutes and Homemakers' Clubs took up across the country. ${ }^{73}$ The Federated Women's Institutes of Ontario created a series of sub-committees to promote various aspects of their club work. One of these committees, dedicated to "Home Economics," tried to provide a forum for discussion on a whole range of issues. These included the question of substandard rural housing. "How to remodel and make more convenient the old house is one of the leading problems, since building is very expensive," one publication conceded. At the same time, the Women's Institutes took up "the study of labour-saving devices, equipment and methods...making for greater efficiency in rural homes." ${ }^{74}$ The demonstrations of new appliances and techniques were entertaining to women, but with access to rural hydro still decades off in many parts of the country, the idea of modernized farm homes was little more than a dream. ${ }^{75}$ This logic was commonly offered as a strategy to resolve rural depopulation: when farmwomen were exposed to these conveniences, they would decide to stay on the farm. In fact the opposite was often true. When rural women realized how primitive their living conditions were compared with those in urban places, some were even more determined either to leave themselves, or certainly to encourage their daughters to do so.

The irony of the instruction strategy embedded in The Agricultural Instruction Act ran very deep. Introducing farmwomen to standards of living that they could not hope to achieve often served to strengthen their resolve to escape the farm. This was certainly not the end that the framers of the Act had envisioned when they created funding to educate farm people and to inspire them to achieve higher standards of living through farm improvement. Dwayne Cox argues in the case of Alabama that "while agents believed rural life imparted distinctive virtues, they also wanted life on the farm to be more like life in the city. In this

73 Again, reports of American activity on this front were very similar to those across Canada. See Moss and Lass, "A History of Farmers' Institutes," 160-61; and Hoffschwelle, "Better Homes on Better Farms," 60-64.

74 Ambrose, For Home and Country, 102.

75 Ibid., 167-68. For more on the history of hydro expansion across Ontario, see Neil Freeman, The Politics of Power: Ontario Hydro and Its Government 1906-1995 (Toronto: University of Toronto Press, 1996). The American case is quite different because rural electrification was part of the New Deal, particularly the work of the Rural Electrification Administration, established in 1935. See Danbom, Born in the Country, 220-23, and Katherine Jellison, Entitled to Power: Farm Women and Technology 1913-1963 (Chapel Hill: University of North Carolina Press, 1993). 
respect they held contradictory assumptions and promoted contradictory goals." 76

One can also speculate that another unintended outcome of this well-intended Act was to strengthen the resolve of rural people, both men and women, to support the farm parties that promised to address the needs of the farm community more directly. It is more than simply a coincidence that support for third parties such as the United Farmers and the Progressives grew during the years that the much-criticized Agricultural Instruction Act was in place. As Kerry Badgley points out, "In the 1919 [Ontario] provincial election the UFO received 21.7 percent of the popular vote. In 1921 the Progressives received 27.7 percent of the popular vote in the province: there was evidence of momentum at that point."77

In 1924, Liberal Prime Minister William Lyon Mackenzie King cancelled The Agricultural Instruction Act despite the fact that various provincial administrators campaigned vigorously to have the funding extended. David Jones offers at least four explanations for that cancellation, including poor results, poor administration on the part of the provinces, tremendous federal indebtedness after the First World War, and partisan politics. The fact that this grant was a Conservative initiative resulting from an election promise in 1911 meant that Liberal Prime Minister Mackenzie King did not feel bound to extend it. ${ }^{78}$

What kind of impact did The Agricultural Instruction Act have on rural women? Certainly not the kinds of outcomes that Martin Burrell and the country-life idealists had hoped for. Statistics show that the Act did not help to curb rural depopulation nor did it help to make women any happier in their rural settings. An examination of the funding directed toward Women's Institutes and Homemakers' Clubs shows that women's work only represented a small percentage of provincial expenditures. Indeed it seems that the larger the province, the smaller the proportion of funding earmarked for women's clubs. Ontario, the most populous province, was also the least generous toward women's work, as we have seen.

Moreover, the kind of instruction offered to women did little to encourage them to remain on the farm, let alone remain there happily. Ironically, through The Agricultural Instruction Act,

76 Dwayne Cox, “Alabama Farm Agents, 1914-1922," Alabama Review (Oct. 1994): 302-3.

77 Badgley, Ringing in the Common Love of Good, 81.

78 David C. Jones, "Agriculture, The Land and Education," 286. 
women learned a great deal. But the lessons they took away were not the ones their funding providers hoped to pass along. Politicians and country-life idealists were convinced that if farmwomen could only learn to enjoy rural living then the problems of the countryside would be solved. Through groups like the Women's Institutes and Homemakers' Clubs, rural women learned about the latest details of consumer products, convenient appliances, and comfortable homes. Women flocked to these clubs funded by The Agricultural Instruction Act. And they did learn. But no one could have predicted the outcome of this program of instruction. It is not that women learned how to be happy and make a better living off the farm. Rather they learned that to be happy, the living just might be better - OFF the farm. 
Table 1: 1920 Women's Groups Funding as \% of Total Grant

\begin{tabular}{|l|r|r|r|}
\hline \hline Province & $\begin{array}{l}\text { The } \\
\text { Agricultural } \\
\text { Instruction Act } \\
\text { grant }\end{array}$ & $\begin{array}{l}\text { Amount of } \\
\text { Grant } \\
\text { Given to } \\
\text { Women's } \\
\text { Groups* }\end{array}$ & $\begin{array}{l}\text { Percentage } \\
\text { of total }\end{array}$ \\
\hline PEl & $\$ 31,749.22$ & $\$ 2,566.00$ & 8.08 \\
\hline Nova Scotia & $\$ 81,716.69$ & $\$ 4,000.00$ & 4.89 \\
\hline New Brunswick & $\$ 64,110.80$ & $\$ 9,300.00$ & 14.51 \\
\hline Quebec & N* & $\$ 271,113.76$ & $\mathrm{~N} / \mathrm{A}$ \\
\hline Ontario & $\$ 336,303.26$ & $\$ 5,000.00$ & 1.49 \\
\hline Manitoba** & $\$ 77,113.11$ & $\mathrm{~N} / \mathrm{A}$ & $\mathrm{N} / \mathrm{A}$ \\
\hline Saskatchewan & $\$ 81,728.48$ & $\$ 7,500.00$ & 9.18 \\
\hline Alberta & $\$ 66,965.62$ & $\$ 9,500.00$ & 14.19 \\
\hline $\begin{array}{l}\text { British } \\
\text { Columbia* }\end{array}$ & $\$ 69,199.06$ & $\mathrm{~N} / \mathrm{A}$ & $\mathrm{N} / \mathrm{A}$ \\
\hline \multicolumn{1}{|c|}{ Total } & $\$ 1,080,000.00$ & $\$ 37,866.00$ & 3.51 \\
\hline
\end{tabular}

Source: Compiled from The Agricultural Gazette 7, 9 (Sept. 1920): 729-33.

* While all provinces were required to report their budgets of The Agricultural Instruction Act money, they were not required to do so in a regulated format. Thus I have decided to include all budget lines referring to "Women's Institutes," "Women's Clubs," and "Women's Work" in "Women's Groups." Also, certain provinces included budget lines for "domestic science," "household science," and "home economics." However, I have not included this money in my calculations because these funds were primarily directed to programs for schoolchildren and the wages of instructors who taught domestic science courses rather than to the activities of women's clubs directly.

** Quebec and Manitoba did not report an allotment for women's groups in The Agricultural Instruction Act budgets, 1920-21.

*** Women's Groups in British Columbia were not funded by money from The Agricultural Instruction Act, 1920-21. 
"Better and Happier Men and Women” 


\begin{tabular}{|l|l|r|r|r|}
\hline \multicolumn{5}{|c|}{$\begin{array}{l}\text { Table 2: } 1920 \\
\text { Women's Groups }\end{array}$} \\
\hline Province & Members & \multicolumn{1}{|l|}{ Branches } & $\begin{array}{l}\text { \$ per } \\
\text { member }\end{array}$ & $\begin{array}{l}\text { \$ per } \\
\text { branch }\end{array}$ \\
\hline PEl & 750 & 34 & $\$ 3.42$ & $\$ 75.47$ \\
\hline Nova Scotia & 17000 & 55 & $\$ 0.24$ & $\$ 72.73$ \\
\hline New Brunswick & 5000 & 134 & $\$ 1.86$ & $\$ 69.40$ \\
\hline Quebec* & 1090 & 50 & $\mathrm{~N} / \mathrm{A}$ & $\mathrm{N} / \mathrm{A}$ \\
\hline Ontario & 30000 & 900 & $\$ 0.17$ & $\$ 5.56$ \\
\hline Manitoba* & 2600 & 127 & $\mathrm{~N} / \mathrm{A}$ & $\mathrm{N} / \mathrm{A}$ \\
\hline Saskatchewan & 5000 & 180 & $\$ 1.50$ & $\$ 41.67$ \\
\hline Alberta & 12000 & 265 & $\$ 0.79$ & $\$ 35.85$ \\
\hline $\begin{array}{l}\text { British } \\
\text { Columbia }\end{array}$ & 3000 & 68 & $\mathrm{~N} / \mathrm{A}$ & $\mathrm{N} / \mathrm{A}$ \\
\hline \multicolumn{1}{|c|}{ Total } & 76440 & 1813 & $\$ 0.50$ & $\$ 20.89$ \\
\hline
\end{tabular}

Source: Membership/Branch data compiled from The Agricultural Gazette 7, 3 (Mar. 1920): 232-240; and calculations (per member, per branch) based on provincial budget reports printed in The Agricultural Gazette 7, 9 (September 1920): 729-733.

* Quebec and Manitoba did not report an allotment for women's groups in The Agricultural Instruction Act budgets, 1920-21.

**Women's Groups in British Columbia were not funded by money from The Agricultural Instruction Act, 1920-21. 